\title{
Exploration of Ngawi Batik Ethnomatematics to Unlock Philosophy Values and Mathematics Concepts
}

\author{
N Fathikhin ${ }^{1}$, P Wijayanti ${ }^{2}$ \\ ${ }^{12}$ Mathematics Education, Faculty of Mathematics and Natural Sciences, State University of \\ Surabaya, Indonesia \\ Email: nurulfathikhin16030174012@mhs.unesa.ac.id
}

\begin{abstract}
Ethnomathematics is mathematics that is developed and applied by certain cultural groups by local culture by considering other knowledge, one of the cultures that developed in Ngawi is Batik. The purpose of this study was to obtain a description of the ethnomathematics of Ngawi batik in UMKM Widi Nugraha and a description of the use of ethnomathematics in Ngawi's typical batik in mathematics learning. To achieve these objectives, researchers used qualitative research methods with ethnographic methods. The results show that Ngawi batik has several philosophical values, namely the history of the name Ngawi which is reflected in Ancient Human batik with a combination of bamboo motifs, preservation in the discovery of ancient fossils stored in the Trinil museum reflected in the batik motifs of Early Man and Batik Kawung Gading, as well as there are flora and fauna found in Ngawi such as, Srigati Series batik and, Teh Jamus batik. In terms of the use of ethnomathematics, namely as a source of information on the batik tradition of the Ngawi community and can be used as a reference in designing realistic mathematics learning in schools. This learning material is in the form of material on symmetry, transformation, and congruence.
\end{abstract}

Keywords: Batik Ngawi, Ethnomathematics

\section{INTRODUCTION}

These guidelines, written in the style of a Culture is a nation's wealth that reflects the identity of a nation. This is in line with [1] opinion that culture is the identity of an area that is different from other regions, created by people in ancient times, and continues to be maintained and preserved by its inhabitants until now. The cultural results are in the form of ideas or ideas, human activities, and the results of these activities.

Culture can be understood as beliefs, knowledge, and conceptions or it can also be understood as patterns of meaning that have been historically constructed and manifested in symbols and language[2]. Where humans develop their knowledge through experience as one of the life sciences. This is in line with cultural theory, which is something that cannot be avoided in everyday life because the culture is a complete and comprehensive unity that applies in a community[3]. This allows scientific concepts in education to be contained in certain cultural activities.

The Indonesian nation is a nation that has a variety of cultural riches, one of the cultures that have developed and are in the spotlight of the world, namely batik, which has been designated by UNESCO as Masterpieces of the Oral and Intangible Heritage of Humanity on October 2, 2009. Indonesia determines that every 2 October is The commemoration of National Batik Day is a 
form of pride for the Indonesian people towards batik which has gained worldwide recognition for its cultural heritage that should be developed and preserved. One of them is the Ngawi batik. Batik Ngawi has its own uniqueness from other regional batiks through the selection of motifs and how to make batik passed down from generation to generation to preserve the batik culture and features of the city of Ngawi. There are two biggest businesses in making batik in Ngawi, namely in Banyubiru Village, Ngrambe District, and Munggut Hamlet, Munggut Village, Padas District. Through the two regions, the most distinctive motifs with the history and culture of Ngawi are made, namely the production in Munggut Village, Padas District, Ngawi Regency. One of these motifs is the Early Man motif, the Srigati Series motif, the Roh Jati motif, the Jamus Tea motif, the Kawung Gading motif. According to Kanang, the Regent of Ngawi, in the 2019 batik fashion fair, this UMKM was one of the pioneers of Ngawi batik who first developed Ngawi culture into a batik motif. It also actively participates in cultural and arts events, both regional and international.

This Ngawi batik motif has a different and unique meaning and history. For example, the Primordial Man batik motif, this motif contains high cultural and historical values. The discovery of early humans found fossils of ancient human skulls, Pitencatropus Erectus, which at that time were found by Eugene Dubois from the Netherlands. Not only fossils of ancient human skulls, Pitencatropus Erectus, there are also thousands of ancient fossils including animals and other ancient humans, such as fossils of ancient elephant tusks (Stegodon Trigonocephalus Ivory Trinil Area), fossils of molar teeth of elephants (Stegodon Trigonocephalus Upper Molar Trinil Area), fossil bones tiger mandible ( Felis Tigris Mandi Bula Trinil Area), bull horn fossil (Bibos Palaeosondaicus Horn Trinil Area), buffalo horn fossil (Bubalus Palaeokerabau Horn
Trinil Area[4]. From the history of human discovery, the preservation of these findings is appreciated into a work of human motif in antiquity. besides, this motif as an icon of Ngawi typical motif for this motif distinguishes between other areas.

Ngawi batik, which has characteristic motifs taken from Ngawi history and culture, is one of the reasons the Ngawi government held the Ngawi batik fashion fair as one of the steps to preserve the culture that has eroded in the $21 \mathrm{st}$ century. According to the researchers, this is because some of the younger generations choose modern ways of dressing with all kinds of contemporary clothing designs. This design, embracing the various times according to the needs of wearing these clothes. However, in the implementation of the batik fashion fair, Ngawi only preserves the culture through fashion trends which among the participants of the activity do not cover all the people and generations of Ngawi youth. Therefore, the preservation of Ngawi batik has not run optimally to preserve culture. Another alternative in cultural preservation can be applied to the cultivation of cultural education from an early age, either in the family or community. Also, another alternative is through education which is expected to produce a good generation of the nation and can reduce the causes of cultural problems. The existence of this education is very effectively applied in learning at school, considering that almost half of the children's time is spent in the school environment besides the rest in the community and family. In this community and family environment, they use knowledge as experience with everyday things as well as exploration experiences while on vacation. These two sides can complement the learning system from different sides with the same goal.

Cultural values are very important as a foundation for the national character in instilling in each individual from an early age so that they can better understand, understand the meaning, and appreciate and realize the importance of cultural values in carrying out 
every activity of life. Cultivating cultural values can be done by providing understanding and application in the family, education, and community environment. This is in line with [5] saying that preserving regional culture and developing national culture through education both through formal and non-formal education by reactivating all educational platforms and activities. Non-formal education is education that is obtained indirectly which is marked by an increase in someone's knowledge or experience. While formal education is obtained in schools, namely through a learning process with various subjects, one of which is mathematics. Included in Law no. 20 of 2003 concerning the national education system in article 37 emphasizes that mathematics is one of the compulsory subjects for students at the primary and secondary levels.

Mathematics is one of the basic branches of knowledge needed in daily activities, for example, buying and selling, measuring, counting, and so on. The application of mathematics certainly makes it easier for us to carry out our daily activities. This is in line with the research of [6] from the results of her research that the process of making or designing kebaya Kartini indirectly applies the mathematical concept, namely the process of making patterns on the kebaya Kartini design on the front, back and sleeve of the kebaya. As it was said at the beginning that culture is something that we cannot avoid in our daily life and Indonesia has cultural diversity, so it can be said that there is diversity in the application of mathematics to each culture. Mathematical concepts that are embedded in culture and recognize all cultures and develop cultures with unique methods to understand and change their realities, which are then called ethnomathematics.[7]

Ethnomathematics was first introduced by one of the educators from Brazil, D'Ambroso in 1977. The prefix "ethno" is defined as something very broadly referring to the sociocultural context, including language, jargon, code of behavior, myths, and symbols. The root word "mathema" tends to mean explaining, knowing, understanding, and carrying out activities such as coding, measuring, classifying, summarizing, and modeling. The suffix "tics" comes from techne, and has a similar technique.[6] D 'Ambrosio [8]) states that:

"Ethnomathematics aims to acknowledge that there are different ways of doing mathematics taking into account the academic mathematical knowledge that has been developed by different sectors of society as well as considering the different modes in which different cultures negotiate their mathematical practices (how to classify, count, measure, designing buildings or tools, playing and others) ".

So it can be said that ethnomathematics is mathematics that arises, develops, and is practiced by certain cultural groups following the local culture by considering other knowledge. Because it emerges and develops from culture, the existence of ethnomathematics is often not realized by people who use ethnomathematics science. This is because ethnomathematics often looks "simpler" than the formal forms of mathematics found in schools. Local people who usually use ethnomathematics may feel insecure about their ancestral heritage because mathematics in this culture is not written down and interpreted as definitions, theorems, and formulas as is commonly found in academic mathematics.

By applying ethnomathematics in mathematics learning can make it easier for students to understand the material and interpret learning. The mathematics presented in a cultural form will make a major contribution to school mathematics. This is because schools are different social institutions that allow social relations between cultures and one another[9]. One of the roles of the teacher in this learning is to explain relevant contextual meanings related to mathematics learning that 
is applied in the culture of the community in which these students live.

The existence of ethnomathematics that grows and develops from culture makes cultural actors unaware that mathematics looks simpler than the formal form found in schools. Therefore, the researcher is interested in conducting research entitled: Exploration of Ethnomatematics of Ngawi Batik to Reveal Philosophical Values and Mathematical Concepts.

The purpose of this study is to obtain a description of the ethnomathematics of Ngawi batik in Munggut Village, Padas District at UMKM Widi Nugraha, and a description of the use of ethnomathematics in Ngawi's typical batik in obtaining a reference for mathematics learning. The relevant research is research conducted by [1] entitled Ethnomathematic Exploration of Cirebon Trusmi Batik to Unveil Philosophical Values and Mathematical Concepts. In this research, it shows that Trusmi Cirebon batik has elements of mathematical elements, including geometric concepts, transformation (reflection, translation, and rotation), and congruence. Also, there is research conducted by [10] entitled Ethnomatematics of Weaving and Ume Kbubu motifs in North Central Timor Regency for Mathematics Learning in Elementary Schools. The result of this research is that there are mathematical concepts in the woven fabric motifs and ume khubu. Among them is the concept of a line, kite, rhombus, cone, ball, circle, and tube.

\section{METHOD}

The type of research chosen is qualitative research using an ethnographic approach. Qualitative research is research that is used to investigate, find, describe, and explain the number of features of social influences that cannot be explained, drawn, or measured through a quantitative approach [11]. Meanwhile, the ethnographic approach is a theoretical and empirical approach that aims to obtain in-depth descriptions and analysis of
Ngawi batik and its philosophical values and mathematical concepts.

In this study, researchers took samples at UMKM Widi Nugraha Jl. Wachid Hasyim No. 03 Nglarangan, Karangasri, Ngawi and Munggut Village, Padas District, Ngawi Regency, East Java because it is one of the largest Ngawi Batik MSMEs and one of the pioneers of the Ngawi batik motif which has cultural and historical elements in Ngawi district.

The research instrument consists of the main and supporting instruments. The main instrument is the researcher himself who will later be tasked with exploring the activities and motifs of Ngawi's batik and collecting data on mathematical ideas and concepts in Ngawi batik. While the supporting instruments consist of exploration guidelines, interview guidelines, and documentation guidelines.

To collect data, researchers need several techniques, namely literature study, exploration methods, interview methods, and documentation. In some of these techniques, some data is obtained which will be used to compare the results of these data to obtain data validity. Furthermore, in analyzing the data, the researcher used several analyzes, namely: a. Domain analysis: to get an overview through interviews, b. Taxonomic analysis: to obtain detailed data and culture through an overview of the domain analysis, c. Component analysis: to find the cultural meaning contained.

Broadly speaking, the research procedures to be carried out in this study are following the research procedures that adopt an ethnographic approach [12], containing: a. Assign informants, b. Conduct interviews with informants, c. Make ethnographic notes that include field notes, image recording devices, artifacts, etc. d. Make a descriptive question asking, e. Perform ethnographic interview analysis, f. Make a domain analysis, g. Make structural inquiries, p. Perform taxonomic analysis, i. Start writing ethnography (the researcher then provides a narrative explanation of the essence of the findings understudy and 
gets the meaning of the informant's experience).

\section{RESULT AND DISCUSSION}

Sufism Ngawi batik research activities at Widi Nugraha's UMKM were carried out on April 6June 30, 2020. Widi Nugraha's UMKM was founded by Mrs. Siwi Riyayanawati. The following is the result of the interview.

Researcher: When was Widi Nugraha batik Ngawi standing ma'am?

Informant: Founded in December 2010

Researcher: How is the history of the founding of Widi Nugraha batik Ngawi, ma'am?

Informant: History was founded because my child named "Antonius Widi Nugraha" who has special needs, namely deaf. This motivates me to provide education so that he is independent and has expertise in society. Finally, he became interested in the design of clothes and motifs and making batik. After he graduated my son and I started a batik business that was not yet in Ngawi. Finally, I explored the Ngawi area to find good motive ideas.

Researcher: From that exploration, what kind of idea did you finally get?

Informant: At first I went to the Trinil Ngawi Museum and I got the Trinil 1 motif or Early Man batik. Then our son collaborated with the fashion designer Ngawi to develop a nuanced batik motif that characterizes the city of Ngawi.

Researcher: Of the hundreds of motives that were created, have you documented them?

Informant: Some have been documented, some have not had time.

Researcher: Of the many motives, which one is superior, ma'am?

Informant: The flagship batik is Ngawi's signature batik through natural coloring with fossil motifs with various ancient flora and fauna combined with the "Srigati Series" trend. Later, please have a look and take a photo if needed, the problem is one name but the motive is different.

There are hundreds of batik motifs that have been created since its inception. Unfortunately, the number of motives is not fully documented, so the researcher only gets a few domains as the research sample. The choice of this domain was taken based on Widi Nugraha Batik's superior batik categories, including Early Human I Pithecanthropus Erectus batik, Kawung Gading batik, Alam Srigati stamped batik, and Jamus Tea stamped batik, the following are one of Widi Nugraha's superior batik motifs and explanation of philosophical values and mathematical concepts:

\section{Early Human Batik / Pithecanthropus Erectus}

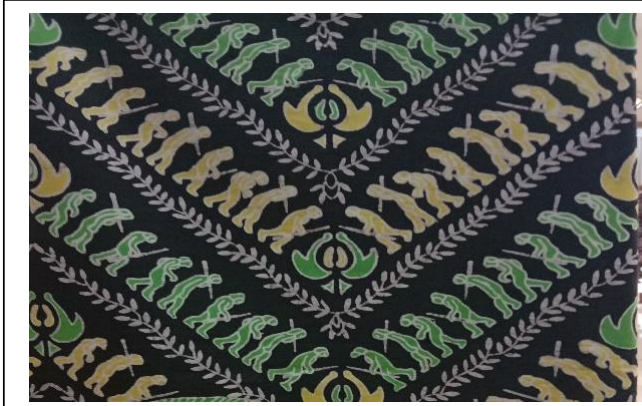

Figure 1.1 Early Human Batik

Early Human Batik is one of the leading batiks in Ngawi. The name of this ancient human was familiar to the Ngawi people because of the fossil findings stored in Ngawi. So that many customers wear this motif, one of them is the family of the father of former Indonesian president Bambang Susilo Yudhoyono in his son-in-law's Instagram photo. Then the researcher interviewed about how to make it together with Mrs. Siwi. The following are the results of the interview.

Researcher: What technique is this batik, ma'am?

Informant : This is homemde batik, sis

Researcher: How is it made ma'am? 
Informant: I followed the guidelines of the course in Jogja, sis, after this I will give you a note. For the general process, later visiting the production site happens that today there are activities after a long pandemic.

Researcher: Fine ma'am, thank you.

Informant: you're welcome

Based on the interview with Mrs. Siwi, this batik is in the category of written batik, it means that in the process of using a canting (the tool is made of copper which is formed to accommodate the wax/batik wax). The following is the process of making ancient human batik;

a. Making sketches of early human motifs on cloth with a pencil. For the image to be the same or the size, sketch the image with the same pattern. Vary each image with different-kinds of patterns. If the picture has finished filling all the fabrics, the early Man batik motif will be formed.

b. Start making batik on the cloth using the canting-write according to the pattern.

c. Use canting with the contents of the liquid wax to coat the desired motif and use it according to its intended purpose so that when the process of dipping the material in the dye solution, the part that is given a wax coating is not exposed. Then when the wax is dry enough, dip the cloth in the color solution.

d. Cover the parts that will remain white (colorless) with wax. Canting is used on the smooth side and brush on the large part. The goal is that in the process of immersing the material into the dye solution, the part that is given a wax coating does not hit it.

e. Perform the first staining process on the part that is not covered by wax. You do this through the process of dyeing the fabric in the desired color.

f. Dry the cloth and protect it from direct sunlight.

g. Perform the batik process again by closing the part that will be retained in the first coloring.

h. Do the process of dyeing the fabric in the second color

i. Remove the wax from the fabric in the previous step by placing the cloth in hot water on the stove.

j. Do the batik process again by covering the candle with a canting so that it holds the first and second colors.

k. Spotting or nglorot. This step uses a cloth that has changed color, boil it with hot water. The purpose of this process is to remove the wax so that the previously drawn motif is clear.

1. Bliriki, which is to continue re-closing so that the desired parts are closed completely.

m. Wash the cloth then dry it in the sun without sunlight.[13]

Based on the interview, this motif is the first motive originating from the idea of a cultural and historical visit to the Trinil Ngawi museum. The philosophy contained in this batik motif is a description of ancient history with the discovery of ancient human fossil skeletons of the Pitencatropus Erectus species. These findings are stored in the Trinil Ngawi museum which is one of the educational tourism destinations. Through the history of the discovery of ancient human fossils, the preservation of these discoveries is appreciated as batik motifs. Also, this ancient human batik motif is a characteristic of batik motifs that distinguishes it from other regional batiks. 


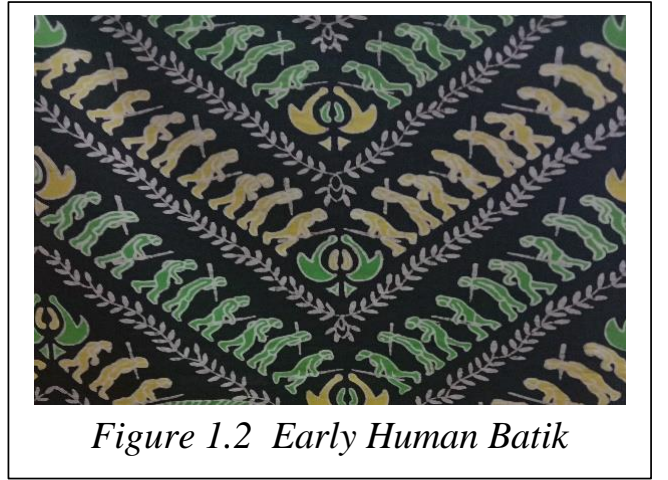

Pay attention to the object that is carried in the picture, there is a bamboo spear on the Primitive Man's batik motif. This also cannot be separated from the origin of the name Ngawi. The idea of taking the theme of naming Ngawi district which comes from the word " awi" which means bamboo, then there is an additional nasal letter "ng" to become "NGAWI"[14]. In addition to the meaning of Ngawi which comes from " awi", the word also indicates a location around the outskirts of Bengawan Solo and Bengawan Madiun where many "awi" trees are found growing lush and dense. This made it possible for ancient activities to often use bamboo as a plant to sustain life. Bamboo plants also have other very valuable meanings, namely:

a) Buddhist perspective, the bamboo forest is a holy place

b) In daily activities, bamboo for the village community has an important role, one of which is during the development period.

c) The meaning of bamboo in the struggle for independence of the Republic of Indonesia has historical value, namely in the form of "sharp bamboo" which was used as a weapon against and expelling invaders. It turns out that this bamboo weapon is feared by the opponent because it is depicted that a sharp bamboo stab will suffer a long and painful pain [3]

The batik motif is a combination of hunting movements using bamboo spears in the era of ancient humans at that time. The taking of this combination of movements/poses is a variation of motives and an introduction to hunting movements in ancient times. The combination of movement/pose motives is made to reflect each other from the line of motif made with this combination motif.

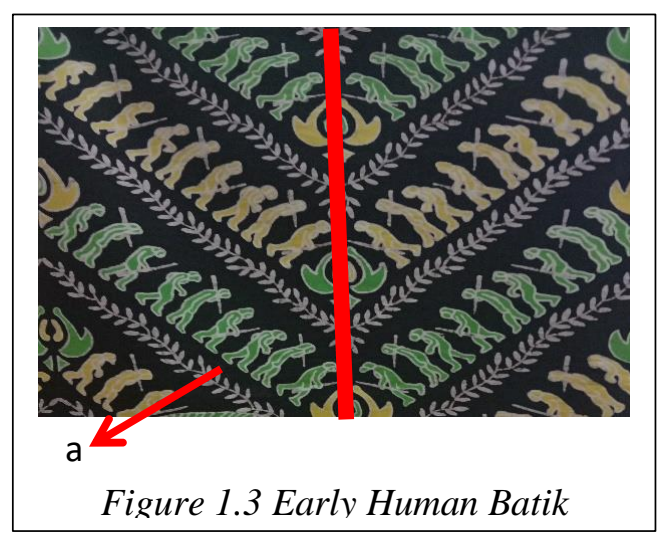

This batik motif applies the concept of reflection in making sketches of the motif. For example in making motifs in Figure 1.3. in this picture a motif is made, which is then put on the left side, above and in other positions so that in the end a complete batik motif will be obtained.

In daily application, batik can be used as a medium in the stage of student motivation in reflection material. At this stage of motivation, it is an introduction to reflection material in everyday life so that students are enthusiastic about learning reflection material and eliminate the stigma of thinking that mathematics is difficult. For example, "children pay attention to this batik motif. What do you know about this motive? These sentences will stimulate students to think critically about the questions raised by the teacher. The possibility that the students will answer is "a picture of a person, ma'am, there are some movements of a person carrying a stick, and why is the image like the nature of a mirror, ma'am? the picture is facing each other ma'am? Thus the teacher will guide students in discovering new knowledge such as an explanation of ancient humans in Ngawi and afterward towards material reflection (reflection). From this picture, it can be used as motivation in preserving the culture of the Indonesian nation which has been recognized by UNESCO and can be used by the media as a means for students to understand the reflection material 
that the ancient human batik motifs have a reflective nature in the application of daily life.

\section{Batik Kawung Gading}

Due to the knowledge learned by the founder of Widi Nugraha batik Ngawi from Jogjakarta, this has influenced his ideas and methods of production. So that kawung is synonymous with the kingdom like the Jogjakarta region. Kawung according [15] is a cloth worn by the king and his closest family as a symbol of justice and courage. Usually, there are four circular or oval shapes with a center point representing the king who is accompanied by his maids. Based on the development of the kawung era, it can be used by all people. On the other hand, Kawung Gading batik is one of the characteristics of the Ngawi area with the discovery of ancient fossils found in the Trinil area and now also stored in the Trinil Kedunggalar Ngawi museum. It is known that based on the documentation in the Trinil museum there is an ancient elephant life in the Ngawi area. Thus, we should appreciate it through batik motifs to introduce the history and culture of Ngawi from a national and international perspective.

To preserve this culture requires expertise in making batik. The following is an interview regarding the process of making Kawung Gading batik. The following are the results of the interview:

Researcher: What kind of technique is Batik Kawung Gading in?

Informant: As the name implies, this includes printed batik, sis.

Researcher: What is the difference between hand-written batik and printed batik?

Informant: In the process of making stamped batik, the tool used is a copper metal plate with an embossed motif.

Researcher: What is the principle of how it works ma'am?

Informant: According to the principle of using a metal plate, it is almost the same as using a stamp. Attaching wax/batik wax to the cloth on the cloth through the plate. As in the process of making written batik, the stages in making printed batik are almost the same, starting with giving wax (wax) to the cloth, then the coloring process, and finally releasing the wax from the cloth.

Researcher: What are the next steps after removing the wax from the fabric?

Informant: Next, giving the wax to the stamped batik process requires a table wide enough to roll out the white cloth for the batik. Under this white cloth, it is usually also given a soft base but the surface is flat so that the waxing process of the plate can be better. Giving color to the fabric is in principle the same as the way batik is written, the coloring process begins with white or other colors that are lighter. The plain white cloth can be directly stamped evening or give a light color first then stamped. The coloring process can be done several times as you wish, the more colors there are usually more areas that must be covered with wax/batik wax. Then add additional motifs using canting in the presence of a pencil pattern first. These additional motifs are like dots or flowers for added aesthetics.

Researcher: Then how was the process after that ma'am?

Informant: Furthermore, the process of removing wax (removing wax from the fabric) can be done after applying wax, color, and color enhancement. This process is usually carried out by heating at a certain temperature which is generally done by boiling using clean water. The process of boiling this cloth is applied twice than in the final process with a soda solution to turn off the color attached to the batik and avoid fading. Then after the boiling process is complete, do the process by soaking the batik in cold water and drying it in the sun.

Researcher: What are the tips for drying so that the results are good, ma'am? 
Informant: The tips are to dry in the sun indirectly. If you're in the room, try to get a normal air exchange so the fabric doesn't smell bad. The existence of this air circulation also affects the drying time.

In the interview, it means that the process of making batik has been entrenched since its previous ancestors and is applied in educational institutions both courses and formal education as was done by Mrs. Siwi and her son Widi. This has also decreased in the batik craftsmen around the production, namely in the village of Munggut, Padas District, Ngawi Regency. There are dozens of craftsmen working in this business sector. This is the duty of the nation's future generations to always preserve Indonesian culture.

In making batik motifs it can also be associated with the concept of rotation in flat shapes, namely by rotating the batik motif made according to its axis, for example, in Figure 1.4.

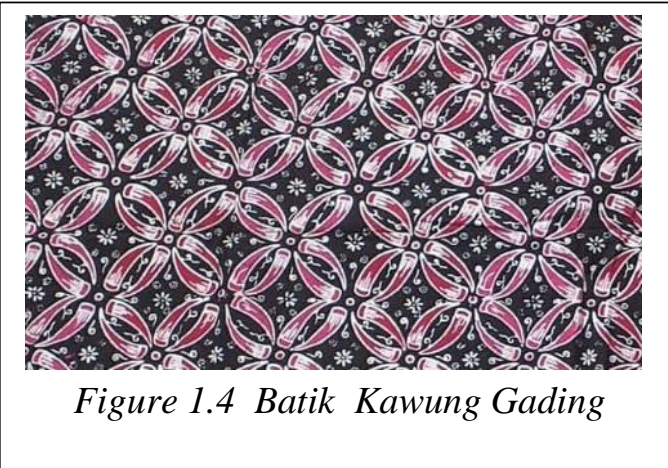

In Figure 1.4 the Kawung Gading motif is rotated 180 from its original position. This application is done over and over again to get the perfect batik motif. Then the craftsman gives a touch of other supporting motifs such as flowers, dots, and various other motives, giving these supporters as a sweetener of batik motifs. From this step, the batik motif will be obtained in Figure 1.4.

Besides that, it can be used as motivation in learning on transformation material to be precise in the rotation material by showing the batik motif as an introduction to the material and explaining the culture contained therein. On the other hand, this motive can be used as material for transformation (rotation) as a realistic material approach through problems or discussion in the material. An example of the problem is the identification of the Kawung Gading batik motif regarding the characteristics contained in the transformation! By giving this example, students can think open-minded about the given problem, so they train critical thinking.

\section{Natural Color Stamp of Srigati Batik}

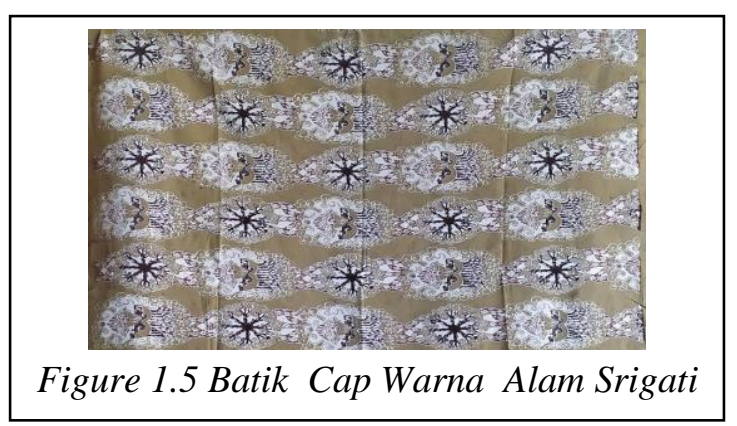

This batik with the natural color of Srigati is classified as the flagship batik in the "Srigati Series" category. The choice of batik is also due to the tourist location in Ngawi as well as the culture and history contained in the meaning of "Srigati Series". The following is an interview with Mr. Johanes Triatmaja as the manager of Widi Nugraha Batik Ngawi as well as the son of Mrs. Siwi Riyayanawati regarding this batik philosophy. The following are the results of the interview.

Researcher: What was the inspiration for making the Srigati Natural Color printed batik motif, sir?

Informant: The natural color stamp of Srigati batik was inspired by the Srigati forest tourism area in the Paron Ngawi area.

Researcher: What is the philosophy contained in the meaning of batik?

Informant: This batik has a philosophy of the richness of flora found in the Srigati forest which can be found today or are extinct. 
Then the researcher visited the tour and asked the surrounding community that there were also some spiritual recollections and the wealth of fauna that thrived in the forest. The following are the results of the interview.

Researcher: What kind of petilasan are there in the srigati forest, sir?

Informant: Spiritual petilasan, namely the ritual place of King Brawijaya $V$ before performing moksa to Mount Lawu. The form of the ritual is to bathe in spring around the Srigati river which is believed to be awaited by the heavenly angel. This activity is carried out as a form of cleansing ourselves physically and mentally when we want to worship or in ancient times stay in sacred locations.

Researcher: Apart from petilasan, what animals and plants live here sir?

Informant: Wow, there are many sis, one of them is the Javan deer, partridge, various types of birds, including the animals. For plants, there are spirits of teak, mahogany, wora-wari flowers, and many others.

From the interview, it was explained that there are cultural and historical meanings in the area in Ngawi which are sketched out batik motifs. So that the meaning contained in this batik is the manifestation of flora found in the Srigati forest.

In the manufacturing process using the stamp technique. Of course, when batik is said to be cultural, it means that there is an element of repetition or grip in the making. This is also explained by Mrs. Siwi that the steps are almost the same as the Kawung Gading batik which is one of the batik techniques with the stamp technique, however, the difference is that the coloring uses natural colors.

From a mathematical point of view, there is a concept of congruence in batik motifs in Indonesia, one of which is in Ngawi. In showing that batik is said to be congruent through the application of making motifs, the sketch that will be made is then given action in a way that is reflected, rotated, or shifted. This is of course through the requirements that the size and motive are the same even though they have been given this measure. For example in the image below.

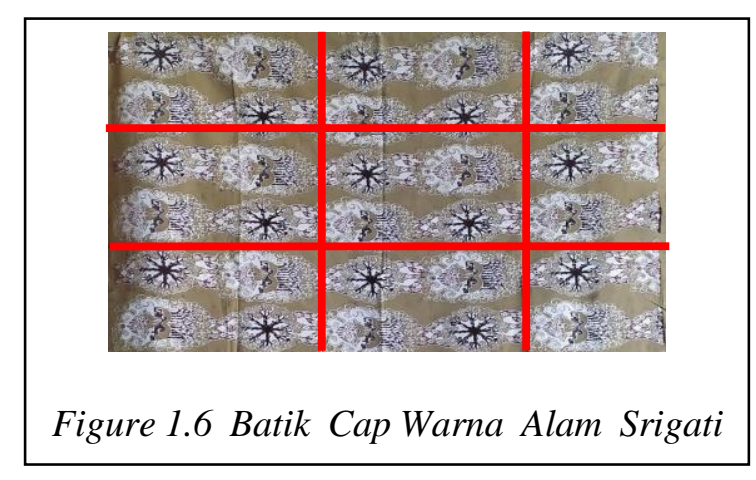

The method of making batik is by using the stamp technique by moving it as far as the original motif then moving it to become a line of Srigati motifs. Thus the vertical side of batik treatment. This can be stamped with a shift or rotated 180 . This also applies to the application of the nature of reflection to the making of this batik motif. So that if it is continued in a fabric size, it can form a perfect batik motif.

Also, there are other mathematical concepts such as determining many batik motifs on a cloth to make it neat and straight. For example, Bu Nurul wants to make printed batik with a size of $2 \times 2$ (meters). Then he used a $20 \times 20(\mathrm{~cm})$ stamp. How many batik motifs will be produced in one cloth? The answer is by using the concept of space and congruence. Because the stamp motifs are congruent and spaced precisely from one motive to another,

a. Area of cloth $=200 \times 200(\mathrm{~cm})=40.000 \mathrm{~cm}$.

b. Motif area $=20 \times 20=400 \mathrm{~cm}$

c. So the number of batik motifs on one cloth is 40.000: $400=100$ batik motifs

\section{Batik Cap Teh Jamus}

According to Mr. Johanes Triatmaja in an interview at the Widi Nugraha outlet, Jalan Wahid Hasyim No. 3 Karangasri Ngawi, the Jamus tea stamped batik was the same as Srigati's natural color stamped batik. The following are the results of the interview: 
Researcher: How did you choose this batik technique, sir?

Informant: In the beginning, the batik motif designer determined the theme of the image/motif. After that the selection of the location to be modified. From this idea, then determine the batik be written or stamped. If it is a stamp, make a mold first according to the finished motif.

Researcher: What is the size of the tool used in the stamping process?

Informant: The size is $20 \times 20(\mathrm{~cm})$.

Researcher: What was the inspiration for this batik motif, sir?

Informant: All of our batiks are oriented towards culture and history as well as things related to Ngawi. One of them is the Jamus Tea tour. This motif is taken from the leaves, stems, the flowers in this jamus tea plant.

From the interview, the fact that this batik motif was inspired by one of the natural tea plantation areas, which are located around the slopes of Mount Lawu, made this tour popular with many people to briefly clear their minds and gather family or closest friends. Also, Jamus Tea plantation tourism has tea products that are different from other plantations including, Tea Jamus Ngawi, Coffee-flavored Jamus Tea, and other products. Thus, UMKM Widi Nugraha thought in creating batik motifs with the appeal of Jamus tea and introducing Ngawi tourism throughout the country and the world. The following is a batik cap Teh Jamus.

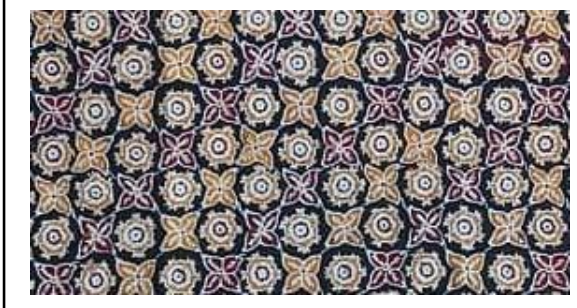

Figure 1.7 Batik Cap Teh Jamus
If viewed from a mathematical perspective, batik has a shifting or translational nature. The following is the explanation.

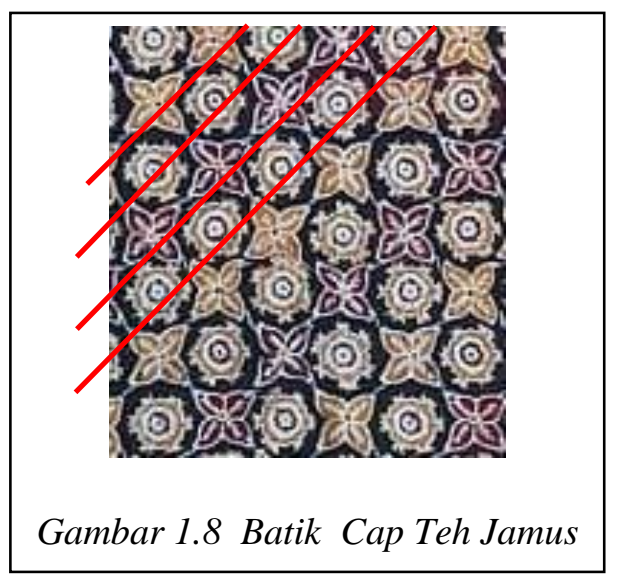

If viewed vertically, the batik motif repeats itself from one leaf to the next. This also applies to subsequent motives. This is due to the concept of a shift through the stamp technique in each process of the batik motif. For this reason, the method of making this motif follows the technique of making Kawung Gading batik.

When viewed in terms of learning steps, this Jamus tea stamp batik is one of the learning media for students in starting translation material. With the Jamus tea motif, it is then associated with the experiences made by students when visiting Jamus tea tours. With a fun start by linking jamus tea tours then directed towards this batik motif. Furthermore, the teacher gives many questions that make students think that there is a translation concept in batik motifs 


\section{CONCLUSION}

The conclusions from the results of data analysis and discussion in this study are as follows;

1. Ethnomathematics contained in Ngawi batik have several philosophical values, namely preservation in the discovery of ancient fossils stored in the Trinil museum and the history of naming Ngawi district is reflected in Early Man batik, Kawung Gading batik, and others, as well as fauna and fauna found in Ngawi such as batik Jamus tea and batik Srigati Series.

2. The use of ethnomathematics in the typical Ngawi batik motif as a source of information on the batik tradition of the Ngawi community and can be used as a means of reference in compiling realistic mathematics learning in schools, for example in the material of symmetry, transformation (translation, rotation, reflection) and congruence

\section{REFERENCES}

[1] Arwanto. (2017). Eksplorasi Etnomatematika Batik Trusmi Cirebon Untuk Mengungkap Nilai Filosofi Dan Konsep Matematis. Jurnal Pendidikan Matematika, Vol 7 No 1

[2] Dokhi, Mohammad (dkk.) 2016. Analisis Kearifan Lokal Ditinjau Dari Keragaman Budaya. Jakarta: Kemendikbud.

[3] Kamaruddin, Muhammad. (2017). Eksplorasi Etnomatematika Masyarakat Madura Pada Pemukiman Tenayan Lanjang. Surabaya: UNESA Press.

[4] Widodo, Dukut Imam. (2017). Ngawi Bertutur. Surabaya. Dukut Publishing

[5] Wulandari, Arya dan Kadek Rahayu Puspitadewi. (2016). Budaya dan Implikasinya Terhadap Pembelajaran Matematika yang Kreatif. Jurnal Santiaji Pendidikan, Volume 6, Nomor 1, ISSN 2087-9016

[6] Zaenuri dan Nurkaromah. (2018). Menggali Etnomatematika: Matematika sebagai Produk Budaya. PRISMA 1 Prosiding Seminar Matematika UNNES. Semarang.

[7] Rosa, Milton \& Orey, Daniel Clark. (2010). Ethnomodeling: A Pedagogical Action for Uncovering Ethnomathematical Practices. Journal of Mathematical Modelling and Application, 1(3), 58-67, 2010
[8] Rachmawati, inda. (2012). Eksplorasi Etnomatematika Masyarakat Sidoarjo. Jurnal Mathedunesa

[9] Sirate, Fatimah. (2012) Implementasi Etnomatematika Dalam Pembelajaran Matematika Pada Jenjang Pendidikan Sekolah Dasar. Lentera Pendidikan, Vol 15 No.1.

[10] Tamelab, Yuventius. (2017). Etnomatematika Motif kain Tenun dan Ume Kbubu Kabupaten Timor tengah Utara Untuk Pembelajaran Matematika di Sekolah Dasar. Tesis Tidak Dipublikasikan. Universitas Negeri Surabaya, Surabaya

[11] Sugiyono. (2016). Metode Penelitian Kuantitatif Kualitatif dan R\&D. Bandung: Alfabeta.

[12] Spradley, James. (2007). Metode Etnografi. Terj. M.Z Elizabeth. Yogyakarta: PT Tiara Wacana. (Buku asli diterbitkan 1979).

[13] Mifzal, Abiyu. (2012). Mengenal Ragam Batik Nusantara. Jogjakarta: Javalitera

[14] Team Perpustakaan, Arsip dan, Dokumentasi Kabupaten Ngawi. (2015). Cerita Rakyat AsalUsul Desa Di Wilayah Kabupaten Ngawi. Kantor Perpustakaan, Arsip dan, Dokumentasi Kabupaten Ngawi

[15] Sa'du, Abdul Aziz. (2013). Buku Panduan Mengenal Membuat Batik. Jogjakarta. Harmoni 